目的に合致した最少の枚数で，最大效果が上がる術式の 組合わせ, 撮影枚数, 体位等, 基準方式的な撮影法の確 立が望まれる。

III 金原 保（恵風園胃腸病院）

1.. 胆䨳収縮像の検詰

アンケート調査でも收縮の時間, 撮影枚数はまちまち であった：我々の方法は，卵黄投与後，35分で第一回目， これで収縮がなかったすのには65分で第 2 回目，更に収 縮がないすのを95分で行ない，収縮について良好な結果 を得ている。

2. 必要に応じ断層撮影を行なっった症例

腸内ガス像や胆需像の示現の程度等により，X線写真 像が紛らわしき症例について, 腹卧位 $20 \sim 30$ 度斜位, 管 球移動軸に体位を平行としたものと，ななめ断層を比較 した.

胆霆部に於ては大きな差はないが，胆道ではななる断 首の方が良好であった。

3. 経口胆霡造影棛の溶解テスト

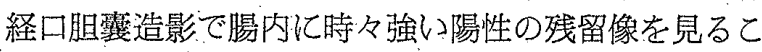
とがある. 造影の不成功は種々の原因があるが, 造影剂 の溶解の程度も個人により差があるすの之思われるので， その溶解を，0.05，0.1 規定㦈酸液, 蒸溜水; $0.1,0.4$ 規定可性ソーダ液を $37^{\circ} \mathrm{C} て ゙$ 恒温槽内で 5 種類の経口造影 㨈を調べた結果，溶解時間に大きな差があった。

4. 当院で昭和 47 年中に䏣孁症で手術した 21 症例より 撮影枚数の検討を試みた.

当院は消化器専門の小病院であるため; 医師との連絡, 打合わせ等むょく，撮影した写真はすへて至急で見てそ の都度基準的撮影法を行なっているので，撮影枚数はア ンケートの結果より少ないが, 手術症例と合わせて写真 を再検討した結果では被曝線量減少の点からも，更に検 討を加える余地がある様に思わ机る。

\section{0. マルチフォトシンチグラム装置の試作}

干葉県がんセンタ一核医学彰療科 木下富士美・小圷 正木

フォトスキャンは打点シンチグラムと比較してコント ラストの良い画像が得られる反面，カウントの少ない部 分では光のスポットがフィルムを黒化するに至らないで， 全く情報が失なわれてしまう恐れがある。又，スリット が大きいと R・I 集積の多い部位での 黒化度の上りすぎ のため解像力の低下を来たす事が多い。我々はでれらの 久点を補う方法としてマルチフォト方式を開発した。 こ れは光源を一定の強さとして，カウント数に比例して発 光回数を增す方式で，4個の光源をもち，入力パルスに
より順次発光させたすのをライトガイドで導きレンズに よって集光させてフィルムの上に小さなスポットをあて るようにしたもので, フィルムの黒化は発光回数の多少 により決まってくる．本方式により打点方式とフォト方 式の両者の長所が取り入れられ，R・I 集積の高い部位や 縮少像などでも比較的解像力の良い解明なフォトジン が得られる。

\section{RI 動態測定の深さに対する感度補正の基礎実験} 神奈川県立成人病センター
伊勢 俊秀・酒井 聡子・中，村 豊 竹 谷 毅・斉藤美紀雄 山本 洋一

〔目的〕I-131，Tc-99m 亿ついて深さに対する感度補 正を目的とした基礎実験を行なった。

[結果】 (1)水中 isoresponse curve 作成(2)水中 $1 \mathrm{~cm}$ ご との各樑さに於る感度とその比較検討.

〔考察】 'X線写真等で深さと体積を予測できる場合に は，深さに対する感度補正が可能である。すなわち，RI が点に近似できる状態で存在する場合には isoresponse curveで補正し希䣋された状態の場合には，目的とする 部分の中心面感度を基準にして各深さの感度を補正する。 しかし，RIの体外測定では体内分布は予想にすざず, 個体差もあるので数種のモデルを作成し，実測して検討 したい.

\section{2. 放射線治療照合システムの使用経験}

帝京大学附,属病院放射線科

○水越 章善・小川 敬寿 針替。栄·米沢 正雄

〔目的〕当大学病院で，射線治療時の誤照射防止及び， 正確な照射記録の作成のため考案した照射条件照合装置 (ベリファイシステム) を息者数 100 名 (2000回照射) に 使用してきた.その使用経験にういて発表した。

〔結果及び考察〕2000回の延べ照射回数で次のような 結果が出た. 1：照合不一致は全体の3.5\% であった。 2. その不一致中で項目別に\%を示すと，(4) $1.7 \%$ (1) 1 \%(60.5\%(3)0.3\%(5)(2) 0\%であった. (4)の照射野の項 目の中では，照射野サイズよりも照射野ナンバーの操作 ミスが多く，サイズとナンバーの項を別々に分けるべき である．照合項目の增加（腹台の高さ，鉛ブロックの位 置等）を求めるが，とれらシステムとしての働きと経済 性から己ずとその限界ああろう. 又とれらシステムの使 用に伴なう技師の学力の増大之照合項目の増加は共に比 例するが，照射の正確性を求める時，必要かつ充分な照 合項目の増加はしかたがないと考える。 どのくらいの照 